Дитяча стоматологія

УдК [616-053.5+616-009.611]:616.31-085

DOI 10.11603/2311-9624.2020.1.11222

(В. В. Гороховський ${ }^{1}$, I. В. Ходорчук ${ }^{2}$, Т. О. Пиндус ${ }^{3}$, О. В. Єфремова ${ }^{4}$, Х. В. Погорецька ${ }^{5}$, Л. О. Пацкань ${ }^{5}$

Одеський національний медичний університет ${ }^{1}$

Одеська міська дитяча лікарня № 1 імені академіка Б. Я. Резника²

Львівський медичний інститут ${ }^{3}$

Львівський національний медичний університет імені Данила Галицького 4

Тернопільський національний медичний університет імені І. Я. Горбачевського МОЗ України ${ }^{5}$

e-mail: gorohovskiyvv@ukr.net

\title{
Дослідження клінічної ефективності комплексного методу лікування гіперестезії зубів у дітей
}

\section{ІНФОРМАЦІЯ}

Надійшла до редакції/Received: 02.02.2019 p.

Ключові слова: стоматологія; діти; комплексний метод лікування; гіперестезія.

\section{АНОТАЦІЯ}

Резюме. У статті представлено результати дослідження впливу комплексного методу лікування гіперестезії твердих тканин зубів У дітей 12 років.

Мета дослідження - вивчити ефективність застосування комплексного методу лікування гіперестезії зубів у дітей 12 років.

Матеріали і методи. У дослідженнях взяли участь 44 дитини віком 12 років із гіперестезією зубів II ступеня тяжкості. Дітей, залежно від методу лікування, поділили на 2 групи. До групи порівняння ввійшли 23 дитини 12 років обох статей, яким застосовували стандартну схему лікування гіперестезії. До основної групи увійшли 23 дитини віком 12 років обох статей. До початку лікування їм проводили санацію та професійну гігієну ротової порожнини. У дітей основної групи застосовували комплексний метод лікування, який ми розробили. У дітей кожної групи визначали індекси розповсюдження гіперестезії зубів та інтенсивності гіперестезії зубів. Для визначення електрозбудливості пульпи зубів із гіперчутливістю ми використовували апарат «PulpTester-P».

Результати досліджень та їх обговорення. У результаті проведених досліджень ми встановили достовірне зниження індексу розповсюдження гіперестезії зубів у дітей основної групи та групи порівняння після проведеного курсу лікування, але цей індекс у дітей основної групи через півроку був в 9,31 раза менше, ніж показник групи порівняння. Показники індексу інтенсивності гіперестезіі зубів через 6 місяців, рік та півтора року засвідчують пролонгований ефект після застосування запропонованого нами методу лікування.

Висновки. Використання комплексного методу лікування дозволяє зменшити прояви гіперестезії зубів у дітей, що підтверджується показниками індексів розповсюдження, інтенсивності гіперестезії зубів та показниками електроодонтометрії. У дітей, яким використовували розроблений метод лікування гіперчутливості зубів, зменшувалась кількість рецидивів захворювання.
Вступ. У статті представлено результати дослідження впливу комплексного методу лікування гіперестезї твердих тканин зубів у дітей 12 років. Запропонований метод лікування зменшує інтенсивність і поширеність гіперестезї зубів у дітей унаслідок збільшення мінералізації твердих тканин зубів, значно зменшує кількість рецидивів захворювання.

Результати аналізу сучасної літератури вказують на високе розповсюдження гіперестезії 
зубів у дітей [1-3]. Одним із провідних механізмів розвитку підвищеної чутливості зубів $€$ демінералізація твердих тканин, яку можуть спричинити як ендогенні, так і екзогенні фактори [3-5]. Важливим екзогенним фактором підвищеної чутливості зубів є споживання їжі 3 підвищеною кислотністю [6-8]. Це необхідно враховувати при виборі методів лікування гіперестезії зубів $[9,10]$.

Метою дослідження було вивчити ефективність застосування комплексного методу лікування гіперестезії зубів у дітей 12 років.

Матеріали і методи. В дослідженнях взяли участь 44 дитини віком 12 років із гіперестезією зубів II ступеня тяжкості. Дітей, залежно від методу лікування, поділили на 2 групи. До групи порівняння ввійшли 23 дитини 12 років обох статей (12 дівчат та 11 хлопчиків), яким застосовували стандартну схему лікування гіперестезії. До основної групи увійшли 23 дитини віком 12 років обох статей (11 дівчат та 12 хлопчиків). До початку лікування дітям проводили санацію та професійну гігієну ротової порожнини. У дітей основної групи застосовували комплексний метод лікування, який ми розробили і який включав призначення 10 процедур евлектрофорезу з 10 \% розчином глюконату кальцію (протягом 5 хв), призначення зубної пасти «R.O.C.S. активний кальцій» протягом місяця, після чого дітям проводили глибоке фторування емалі препаратом «Ftorcalcit- E» («Латус»). Дітям групи порівняння призначали зубну пасту «R.O.C.S. Sensetive миттєва дія». Дітям усіх груп рекомендували застосувати м'які зубні щітки.

У дітей кожної групи визначали індекс розповсюдження гіперестезії зубів (ІРГЗ), індекс інтенсивності гіперестезії зубів (ІІГЗ) до лікування та через 6 місяців, рік та півтора року після проведеного курсу лікування [10]. Для визначення електрозбудливості пульпи зубів із гіперчутливістю ми використовували апарат PulpTester-P.

Результати досліджень та їх обговорення. В результаті проведених досліджень ми встановили достовірне зниження $(\mathrm{p}<0,001)$ ІРГЗ у дітей основної групи та групи порівняння після проведеного курсу лікування, але показник ІРГЗ у дітей основної групи через півроку склав $0,36 \pm 0,04$, що в 9,31 раза менше, ніж показник групи порівняння. Крім того, застосування запропонованого методу лікування підвищеної чутливості зубів значно зменшує кількість рецидивів захворювання, про це свідчать показники ІРГЗ у дітей основної групи через 6 місяців, рік та півтора року. Так, показники дітей основної групи через 6 місяців були в 9,76 раза, через рік - в 7,39 раза та півтора року - в 4,96 раза менше, ніж показники дітей групи порівняння.

Динаміка змін індексу інтенсивності гіперестезії зубів також демонструє ефективність розробленого методу лікування підвищеної чутливості зубів у дітей (табл. 2).

таблиця 1. Динаміка змін індексу розповсюдження гіперестезії зубів у дітей (бали)

\begin{tabular}{|c|c|c|c|c|c|}
\hline Група дослідження & До лікування & $\begin{array}{c}\text { Після } \\
\text { лікування }\end{array}$ & $\begin{array}{c}\text { Через } 6 \text { міся- } \\
\text { ців }\end{array}$ & $\begin{array}{l}\text { Через } \\
1 \text { рік }\end{array}$ & $\begin{array}{c}\text { Через } \\
1,5 \text { року }\end{array}$ \\
\hline $\begin{array}{l}\text { Група порівняння } \\
(\mathrm{n}=22)\end{array}$ & $18,19 \pm 1,12$ & $\begin{array}{c}3,35 \pm 0,35 \\
\mathrm{p}_{1}<0,001\end{array}$ & $\begin{array}{l}7,42 \pm 0,62 \\
\mathrm{p}_{1}<0,001\end{array}$ & $\begin{array}{l}9,02 \pm 0,54 \\
\mathrm{p}_{1}<0,001\end{array}$ & $\begin{array}{c}10,31 \pm 0,52 \\
\mathrm{p}_{1}<0,001\end{array}$ \\
\hline $\begin{array}{l}\text { Основна група } \\
(\mathrm{n}=22)\end{array}$ & $\begin{array}{c}18,23 \pm 1,08 \\
p>0,1\end{array}$ & $\begin{array}{c}0,36 \pm 0,04 \\
\mathrm{p}<0,001 \\
\mathrm{p}_{1}<0,001\end{array}$ & $\begin{array}{c}0,76 \pm 0,05 \\
\mathrm{p}<0,001 \\
\mathrm{p}_{1}<0,001\end{array}$ & $\begin{array}{c}1,22 \pm 0,10 \\
\mathrm{p}<0,001 \\
\mathrm{p}_{1}<0,001\end{array}$ & $\begin{array}{c}2,08 \pm 0,18 p<0,001 \\
p_{1}<0,001\end{array}$ \\
\hline
\end{tabular}

Примітка. $\mathrm{p}$ - показник достовірності відмінностей відносно групи порівняння; $\mathrm{p}_{1}$ - показник достовірності відмінностей порівняно з початковим станом.

таблищя 2. Динаміка змін індексу інтенсивності гіперестезії зубів у дітей (бали)

\begin{tabular}{|l|c|c|c|c|c|}
\hline Група дослідження & До лікування & Після лікування & Через 6 місяців & $\begin{array}{c}\text { Через } \\
1 \text { рік }\end{array}$ & $\begin{array}{c}\text { Через } \\
1,5 \text { року }\end{array}$ \\
\hline $\begin{array}{l}\text { Група порівняння } \\
(\mathrm{n}=22)\end{array}$ & $2,34 \pm 0,20$ & $0,31 \pm 0,03$ & $0,42 \pm 0,04$ & $0,47 \pm 0,05$ & $0,52 \pm 0,05$ \\
$\mathrm{p}_{1}<0,001$ & $\mathrm{p}_{1}<0,001$ & $\mathrm{p}_{1}<0,001$ & $\mathrm{p}_{1}<0,001$ \\
\hline Основна група & $2,37 \pm 0,19$ & $0,08 \pm 0,01$ & $0,10 \pm 0,02$ & $0,12 \pm 0,01$ & $0,17 \pm 0,02$ \\
$(\mathrm{n}=22)$ & $\mathrm{p}>0,1$ & $\mathrm{p}_{1}<0,001$ & $\mathrm{p}_{1}<0,001$ & $\mathrm{p}<0,001$ & $\mathrm{p}<0,001$ \\
& & & & $\mathrm{p}_{1}<0,001$ & $\mathrm{p}_{1}<0,001$ \\
\hline
\end{tabular}

Примітка. p - показник достовірності відмінностей відносно групи порівняння; $\mathrm{p}_{1}$ - показник достовірності відмінностей порівняно з початковим станом. 
Так, у дітей основної групи індекс ІІГЗ після проведеного курсу лікування був в 3,88 раза менший, ніж показник групи порівняння. Показники індексу через 6 місяців, рік та півтора року засвідчують пролонгований ефект після застосування запропонованого методу лікування.

Показники ЕОД наведені в таблиці 3.

Таблищя 3. Динаміка змін показників електроодонтометрії у дітей під впливом лікування гіперестезії зубів у дітей (мКА)

\begin{tabular}{|c|c|c|}
\hline Показник & $\begin{array}{c}\text { Група порівняняння } \\
(\mathrm{n}=32)\end{array}$ & $\begin{array}{c}\text { Основна група } \\
(n=32)\end{array}$ \\
\hline До лікування & $4,43 \pm 0,31$ & $\begin{array}{c}4,48 \pm 0,29 \\
\mathrm{p}<0,1\end{array}$ \\
\hline Після лікування & $\begin{array}{c}3,13 \pm 0,18 \\
\mathrm{p}_{1}<0,001\end{array}$ & $\begin{array}{c}2,26 \pm 0,2 \\
\mathrm{p}<0,001 \\
\mathrm{p}_{1}<0,001\end{array}$ \\
\hline $\begin{array}{l}\text { Через } \\
6 \text { місяців }\end{array}$ & $\begin{array}{c}3,26 \pm 0,15 \\
p_{1}<0,001\end{array}$ & $\begin{array}{c}2,35 \pm 0,12 \\
\mathrm{p}<0,001 \\
\mathrm{p}_{1}<0,001\end{array}$ \\
\hline Через 1 рік & $\begin{array}{c}3,39 \pm 0,15 \\
p_{1}<0,001\end{array}$ & $\begin{array}{c}2,48 \pm 0,13 \\
\mathrm{p}<0,001 \\
\mathrm{p}_{1}<0,001\end{array}$ \\
\hline Через 1,5 року & $\begin{array}{c}4,00 \pm 0,18 \\
\mathrm{p}_{1}<0,01\end{array}$ & $\begin{array}{c}2,74 \pm 0,17 \\
\mathrm{p}<0,001 \\
\mathrm{p}_{1}<0,001\end{array}$ \\
\hline
\end{tabular}

Примітка. $\mathrm{p}$ - показник достовірності відмінностей відносно групи порівняння тієї ж вікової категорії; $\mathrm{p}_{1}$ - показник достовірності відмінностей порівняно з початковим станом.

Після проведеного курсу лікування ми відмічали достовірне зниження показників основної групи та групи порівняння. Але у дітей, яким застосовувався розроблений нами метод, показники ЕОД в 1,38 раза були меншими. Такі зміни свідчать про ефективність застосування запропонованого методу лікування.

Висновки. Використання запропоновано- го комплексного методу лікування дозволяе зменшити прояви гіперестезії зубів у дітей, що підтверджується показниками індексів розповсюдження, інтенсивності гіперестезії зубів та показниками електроодонтометрії. у дітей, яким використовували метод лікування гіперчутливості зубів, зменшувалась кількість рецидивів захворювання.

\section{(). В. Гороховский ${ }^{1}$, И. В. Ходорчук ${ }^{2}$, Т. А. Пиндус ${ }^{2}$, О. В. Ефремова ${ }^{4}$,}

\section{Х. В. Погорецкая ${ }^{5}$, Л. А. Пацкань}

Одесский национальный медицинский университет ${ }^{1}$

Одесская городская детская больница № 1 имени академика Б. Я. Резника ${ }^{2}$

Львовский медицинский институт ${ }^{3}$

Львовский национальный медицинский университет имени Данила Галицкого 4

Тернопольский национальный медицинский университет имени И. Я. Горбачевского

МО3 Украины ${ }^{5}$

\section{Исследование клинической эффективности комплексного метода лечения гиперестезии зубов у детей}

Резюме. В статье представлены результаты исследования влияния комплексного метода лечения гиперестезии твердых тканей зубов у детей 12 лет.

Цель исследования - изучить эффективность применения комплексного метода лечения гиперестезии зубов у детей 12 лет.

Материалы и методы. В исследованиях приняли участие 44 ребенка в возрасте 12 лет с гиперестезией зубов II степени тяжести. Детей, в зависимости от метода лечения, разделили на 2 группы. В 
группу сравнения вошли 23 ребенка 12 лет обоего пола, которым применялась стандартная схема лечения гиперестезии. В основную группу вошли 23 ребенка в возрасте 12 лет обоих полов. До начала лечения детям проводилась санация и профессиональная гигиена полости рта. У детей основной группы применялся разработанный нами комплексный метод лечения. У детей каждой группы определяли индексы распространенности гиперестезии зубов и интенсивности гиперестезии зубов. Для определения электровозбудимости пульпы зубов с повышенной чувствительностью мы использовали аппарат «РulpTester-Р».

Результаты исследований и их обсуждение. В результате проведенных исследований мы установили достоверное снижение индекса распространенности гиперестезии зубов у детей основной группы и группы сравнения после проведенного курса лечения, но этот индекс у детей основной группы через полгода был в 9,31 раза меньше, чем показатель группы сравнения. Показатели индекса интенсивности гиперестезии зубов через 6 месяцев, год и полтора года свидетельствуют об пролонгированном эффекте после применения, предложенного нами метода лечения.

Выводы. Использование предложенного нами комплексного метода лечения позволяет уменьшить проявления гиперестезии зубов у детей, что подтверждается показателями индексов распространенности, интенсивности гиперестезии зубов и показателями электроодонтометрии. У детей, у которых использовался разработанный нами метод лечения гиперчувствительности зубов, уменьшалось количество рецидивов заболевания.

ключевые слова: стоматология; дети; комплексный метод лечения; гиперестезия.

\author{
(C) V. V. Horokhovskyi ${ }^{1}$, I. V. Khodorchuk ${ }^{2}$, T. O. Pyndus ${ }^{3}$, O. V. Efremova ${ }^{4}$, \\ Kh. V. Pohoretska ${ }^{5}$, L. O. Patskan ${ }^{5}$ \\ Odesa National Medical University ${ }^{1}$ \\ Odesa Children's Hospital named after Academician B. Ya. Reznik ${ }^{2}$ \\ Lviv Medical Institute ${ }^{3}$ \\ Danylo Halytskyi Lviv National Medical University ${ }^{4}$ \\ I. Horbachevsky Ternopil National Medical University ${ }^{5}$
}

\title{
Study of the clinical effectiveness of a comprehensive method of treatment of dental hyperesthesia in children
}

Summary. The article presents the results of a study of the influence of comprehensive method for the treatment of hyperesthesia of hard tooth tissues in 12 years old children.

The aim of the study - to learn the effectiveness of the use of a comprehensive method of treating dental hyperesthesia in 12 years old children.

Materials and Methods. The study involved 44 children aged 12 years with hyperesthesia of the teeth degree II of severity. Children, depending on the method of treatment, were divided into 2 groups. The comparison group included 23 children of 12 years of both sexes who used the standard treatment regimen for hyperesthesia. The main group included 23 children aged 12 years of both sexes. Prior to treatment, children underwent rehabilitation and professional oral hygiene. The complex treatment method that was developed by us was used in children of the main group. In children of each group, the indices of the prevalence of hyperesthesia of the teeth and the intensity of hyperesthesia of the teeth were determined. To determine the electroexcitability of dental pulp with increased sensitivity, we used the PulpTester-P device.

Results and Discussion. As a result of the studies, we found a significant decrease in the prevalence index of dental hyperesthesia in children of the main group and the comparison group after the course of treatment, but this index in children of the main group was six months later 9.31 times less than the indicator of the comparison group. The values of the intensity index of hyperesthesia of the teeth after 6 months, a year and one and half year indicate a prolonged effect after the application of the treatment method proposed by us.

Conclusions. Our comprehensive treatment method allows to reduce the manifestations of dental hyperesthesia in children, which is confirmed by the values of prevalence indices, intensity of dental hyperesthesia and indicators of electroodontometry. The children who were subjected to treatment for tooth hypersensitivity decreased the number of relapses.

Key words: dentistry; children; comprehensive treatment method; hyperesthesia. 


\section{СПИСОК ЛІТЕРАТУРИ}

1. Гороховський В. В. Поширеність та причини виникнення гіперестезії зубів у дітей та осіб молодого віку / В. В. Гороховський, С. В. Шпак // Journal of Education, Health and Sport (Польща). - 2017. - № 7 (1). - P. 518-524.

2. Распространенность некариозных заболеваний полости рта в современной стоматологии / В. А. Журбенко, Э. С. Саакян, Д. С. Тишков [и др.] // Международный журнал прикладных и фундаментальных исследований. - 2015. - № 4/2. C. 301-300.

3. Cartwright R. B. Dentinal hypersensitivity: a narrative review / R. B. Cartwright // Community Dental Health. 2014. - Vol. 31, N 1. - P. 15-20.

4. Davari A. Dentin hypersensitivity: etiology, diagnosis and treatment; a literature review / A. Davari, E. Ataei, H. Assarzadeh // Journal of Dentistry. - 2013. - Vol. 14, No. 3. - P. 136-145.

5. Molecular basis of dental sensitivity: The odontoblasts are multisensory cells and express multifunctional ion channels / A. Solé-Magdalena, M Martínez-Alonso, C. A. Coronado [et al.] // Annals of Anatomy. - 2018. -

\section{REFERENCES}

1. Horokhovskyi, V.V., \& Shpak, S.V. (2017). Poshyrenist ta prychyny vynyknennia hiperestezii zubiv u ditei ta osib molodoho viku [Prevalence and causes of dental hyperesthesia in children and young people]. Journal of Education, Health and Sport, 7 (1), 518-524 [in Ukrainian]. 2. Zhurbenko, V.A., Saakian, E.S., \& Tishkov, D.S. (2015). Rasprostranennost nekarioznyh zabolevaniy polosti rta $\mathrm{v}$ sovremennoy stomatologii [The prevalence of noncarious diseases of the oral cavity in modern dentistry]. Mezhdunarodnyy zhurnal prikladnyh i fundamentalnyh issledovaniy - International Journal of Applied and Basic Research, 4 (2), 301-300 [in Russian].

3. Cartwright, R.B. (2014). Dentinal hypersensitivity: a narrative review. Community Dental Health, 31 (1), 1520.

4. Davari, A. (2013). Dentin hypersensitivity: etiology, diagnosis and treatment; a literature review. Journal of Dentistry, 14 (3), 136-145.

5. Solé-Magdalena, A., Martínez-Alonso, M., \& Coronado, C.A. (2018). Molecular basis of dental sensitivity: The odontoblasts are multisensory cells and express multifunctional ion channels. Annals of Anatomy, 1 (215), 20-29.

6. Burdina, G.A. (2016). Giperesteziya zubov i metody
Vol. 215. - P. 20-29

6. Бурдина Г. А. Гиперестезия зубов и методы ее лечения / Г. А. Бурдина // Dental Magazine. - 2016. № 1. - P. 24-29.

7. Нагибина Л. А. Влияние газированных напитков на твёрдые ткани зуба и реставрации / Л. А. Нагибина, Ю. М. Федотова // Стоматология - наука и практика, перспективы развития : юбил. науч.-практ. конф., посвящ. 55-летию стоматолог. фак-та ВолгГМУ : материалы. - Волгоград, 2017. - С. 225-229.

8. Ронь Г. И. Гиперестезия зубов : учеб.-метод. пособие / Г. И. Ронь, Ю. А. Агафонов, А. Н. Козьменко. Екатеринбург : УГМА, 2013. - 49 с.

9. Хощевская И. А. Профилактика и лечение гиперчувствительности зубов у детей и подростков / И. А. Хощевская // Клиническая стоматология. 2014. - № 3 (71). - С. 4-8.

10. Федоров Ю. А. Клиника, диагностика и лечение не кариозных поражений зубов / Ю. А. Федоров, В. А. Дрожжина // Новое в стоматологии. - 1997. Вып. 10. -145 с.

ee lecheniya [Hyperesthesia of teeth and methods of its treatment]. Dental Magazine, 1, 24-29 [in Russian]. 7. Nagibina, L.A., \& Fedotova, Yu.M. (2017). Vliyanie gazirovannyh napitkov na tvyordye tkani zuba i restavratsii [The effect of carbonated drinks on hard tooth tissues and restorations]. Proceedings scientificpractical Conference to the 55th anniversary of the dentist faculty of Volgograd State Medical University: Stomatologiya - nauka i praktika, perspektivy razvitiya Dentistry Science and Practice, Development Prospects. (pp. 225-229). Volgograd: VSMU [in Russian].

8. Ron, G.I., Agafonov, Yu.A., \& Kozmenko, A.N. (2013). Giperesteziya zubov: uchebno-metodicheskoe posobie [Hyperesthesia of the teeth: teaching aid]. Yekaterinburg: UGMA [in Russian].

9. Hoschevskaya, I.A. (2014). Profilaktika i lechenie giperchuvstvitelnosti zubov $u$ detey i podrostkov [Prevention and treatment of dental hypersensitivity in children and adolescents]. Klinicheskaya stomatologiya - Clinical Dentistry, 3 (71), 4-8 [in Russian].

10. Fedorov, Yu.A. (1997). Klinika, diagnostika i lechenie ne karioznyh porazheniy zubov [Clinic, diagnosis and treatment of non-carious dental lesions]. Novoe $v$ stomatologii - New in Dentistry, 10, 145 [in Russian]. 